\title{
Pengaruh Fluktuasi Nilai Tukar Rupiah terhadap Rasio Pertumbuhan Aset Perbankan Syariah
}

\author{
Ahmad Chumaidi Tarmizi dan Muslikhati \\ Program Studi Ekonomi Syariah, Fakultas Agama Islam, \\ Universitas Muhammadiyah Malang \\ E-mail: tarmizi208@gmail.com
}

\begin{abstract}
This research aims to reveal empirical evidences about the influence of exchange rate fluctuations to asset growth ratio of sharia banking, along with how much does independent variable explain dependent variable. The research takes a quantitative approachment, which refer to numeral calculating of research data. This research variabel consists of exchange rate fluctuations as independent variable and asset growth ratio of sharia banking as a dependent variable. Sample selection using purposive judgment sampling method. The sample of this research is sharia bankingin the period between 2008-2016. Data used in this research is secondary data while the techniques of data analysis in this research applied simple linear regression analysis. Results of this study demonstrate that the exchange rate fluctuations variable significantly influence to asset growth ratio of sharia banking variable. Regression coefficient value is $-1,73$ and significant value is 0,029 . The results of this study as well exhibit that the exchange rate fluctuations variable explained $51 \%$ of asset growth ratio of sharia bankingvariable while the remaining $49 \%$ wereexplained by another variable not included in the model.
\end{abstract}

Keywords: Exchange rate, Asset growth ratio, Sharia Banking.

\section{Pendahuluan}

Era Globalisasi menuntut akan adanya kebebasan dalam berekonomi, kegiatan perekonomian antara negara satu dengan lainnya amat terbuka, dimana arus dana sangat mudah mengalir dari suatu negara ke negara yang lain. ${ }^{1}$ Perputaran

1 Faisal Basri \& Haris Munandar, Dasar-Dasar Ekonomi Internasional, Pengenalan dan Aplikasi Metode Kuantitaif, (Jakarta: Kencana, 2010), 10. 
perdagangan komoditi, jasa, modal, dan pasar uang sangat tinggi. Pergerakan dan perubahan lingkungan perekonomian dunia, pergeseran pusat-pusat kekuatan ekonomi, revolusi teknologi dan komunikasi akan menyeret setiap perekonomian nasional ke dalam kancah perekonomian global. ${ }^{2}$ Sebuah perubahan kecil terhadap kinerja ekonomi negara, akan memberikan dampak tertentu pada negara mitra kerja dan juga negara yang memiliki hubungan erat dalam perihal perdagangan. ${ }^{3}$ Perihal pentingnya posisi alat tukar valuta asing dalam dinamika perdagangan internasional, permasalahan utama yang dihadapi bersama oleh para pelaku ekonomi internasional yakni gejolak fluktuasi alat tukar yang sangat tidak menentu, cenderung mengarah kepada negatif, terutama jika dihadapkan pada pembanding mata uang suatu negara berkembang; dalam hal ini Rupiah Indonesia. Terlebih-lebih jika fluktuasi nilai valuta asing tersebut sudah sampai ke dalam derajat volatilitas tinggi, dimana nilai tukar yang cenderung menguat dengan cepat lalu tiba-tiba turun dalam waktu yang cepat pula. ${ }^{4}$

Eksistensi perbankan menempati posisi strategis dalam perputaran dana valuta asing. Perdagangan Internasional yang dilakukan oleh para individu negara sebagian besar melibatkan pihak bank dalam kegiatan pencatatan debet dan kredit pada rekening bank. Dengan demikian transaksi valuta asing melibatkan pertukaran simpanan perbankan (bank deposit) yang ternilai (didenominasi) dalam berbagai macam mata uang. ${ }^{5}$ Sebagian besar perdagangan valuta asing mengacu pada perdagangan antar bank, tempat tersebut merupakan pasar utama perdagangan mata uang asing dipertemukan. ${ }^{6}$ Maka secara tidak langsung pihak bank akan menyimpan beberapa simpanan dana dalam bentuk valuta asing dan akan tercatat dalam aktiva jangka pendek dan jangka panjangdan juga pada aktiva dan pasiva (asset dan liability). ${ }^{7}$

Demikianlah fenomena transaksi perdagangan valuta asing yang terjadi di era globalisasi ini. Seperti halnya dengan bank konvensional yang menerima transaksi valuta asing bagi para nasabahnya, bank syari'ah juga tidak meninggalkan fungsinya sebagai lembaga intermediary yang menyediakan lalu lintas pembayaran. ${ }^{8}$ Perbankansyari'ah juga melakukan transaksi valuta asing bagi para nasabah. Namun kebanyakan transaksi valuta asing yang dilakukan saat ini banyak mengandung unsur gharar (ketidakjelasan) dan maysiir(perjudian). ${ }^{9}$ Hal

\footnotetext{
${ }^{2}$ Ibid, 10 .

${ }^{3}$ Dominick Salvatore, Ekonomi Internasional, Vol. 2, (Jakarta: Penerbit Erlangga, 1997), 106.

4 Hendra Syamsir, Solusi Investasi di bursa saham Indonesia, (Jakarta: Elex Media Komputindo, 2004), 96-97.

5 Dominick Salvatore, Ekonomi Internasional.., hal. 5

${ }^{6}$ Peter H Lindert \& Charles P. Kindleberger, Ekonomi Internasional, Cet. VIII, (Jakarta: Penerbit Erlangga, 1988), 338.

${ }^{7}$ Laporan Keuangan tahunan (annual report). PT Bank Muamalat Tbk. Tahun 2016, 164

${ }^{8}$ Undang-Undang No.10 Tahun 1998 Tentang Perubahan Undang-Undang No.7 Tahun 1992 Tentang Perbankan.

${ }_{9}^{9}$ Adiwarman Azwar Karim, Ekonomi Islam Suatu Kajian Kontemporer, (Jakarta: Gema Insani, 2001), 132-134.
} 
ini sangat bertentangan dengan prinsip bank syari'ah yang berlandaskan AlQur'an dan Hadits Nabi Saw. Implikasinya, volume transaksi valuta asing pada perbankan syari'ah tidak sebanding dengan perbankan konvensional, sehingga risiko fluktuasi kurs dapat terkendali. Namun pada saat ini, perkembangan perbankan umum syari'ahsudah semakin besar.Tercatat bahwa perkembangan perbankan syari'ah dalam kurun waktu sembilan tahun belakang ini mencapai rata-rata 25\% per tahun, total aset perbankan syari'ah pada Maret 2017 telah mencapai sebesar 254 Triliun Rupiah, demikian juga jumlah jaringan seluruh kantor sebanyak 1.869 tersebar hampir di setiap penjuru Nusantara. ${ }^{10}$ Kemudian tidak bisa dipungkiri pula bahwa minat umroh dan haji para nasabah menjadi faktor penting dalam menambah volume transkasi valuta asing bank syari'ah, dengan demikian merupakan sebuah keniscayaan jika volume transaksi valuta asing pada perbankan syari'ah kian bertambah. Berdasarkan latar belakang masalah tersebut, penulis tertarik untuk mengadakan kajian lebih mendalam mengenai perubahan nilai tukar rupiah serta seberapa besar pengaruhnya terhadaprasio pertumbuhan aset perbankan syari'ah.

\section{Nilai Tukar: Definisi dan Ruang Lingkupnya}

Menurut Krugman dan Obstfeld nilai tukar merupakan harga suatu mata uang terhadap mata uang lainnya. ${ }^{11}$ Kemudian dalam bukunya menurut Lindert dan Kindlberger nilai tukar adalah suatu jenis harga atau nilai uang suatu negara yang diukur oleh uang negara-negara lain. ${ }^{12}$ Pengertian nilai tukar dan kurs menurut Salvatore yakni harga suatu mata uang terhadap mata uang lainnya. ${ }^{13}$ Sistem nilai tukar dibagi menjadi beberapa macam, yakni sistem nilai tukar tetap (fixed exchange rate), sistem nilai tukar mengambang (flexible exchange rate), sistem nilai tukar mengambang terkendali (manage floating exchange rate), dansistem nilai tukar terikat (pegged exchange rate). ${ }^{14}$

\section{Aset Bank Syariah dan Kaitannya dengan Valuta Asing}

Bank syari'ah merupakan lembaga keuangan atau perbankan yang operasional dan produknya dikembangkan berlandaskan Al-Qur'an dan Hadits Nabi Muhammad SAW, atau dengan kata lain bank syari'ah adalah bank yang beroperasi dengan tidak mengandalkan pada mekanisme bunga melainkan dengan

\footnotetext{
${ }^{10}$ Statistik Perbankan Syari’ah (SPS). Edisi Juni 2017. Otoritas Jasa Keuangan (OJK).

${ }^{11}$ Paul R. Krugman \& Maurice Obstfeld, Ekonomi Internasional, Teori dan Kebijakan, Vol. II, (Jakarta: Rajawali Press, 1992), 40.

12 Peter H. Lindert \& Charles P. Kindleberger, Ekonomi Internasional, Cet.VIII, (Jakarta: Penerbit Erlangga, 1988), 336.

13 Dominick Salvatore, Ekonomi Internasional, Cet. 5, Vol.II, (Jakarta: Penerbit Erlangga, 1997), 9.

${ }^{14}$ Mahyus Ekananda, Ekonomi Internasional, (Jakarta: Penerbit Erlangga, 2014), 314-316.
} 
sistem bagi hasil. ${ }^{15}$ Kemudian ditegaskan dengan Undang-Undang No.10 Tahun 1998 tentang Perbankan, Bank Syari'ah adalah bank yang melaksanakan kegiatan usaha berdasarkan prinsip syari'ah yang dalam kegiatannya memberikan jasa dalam lalu lintas pembayaran. ${ }^{16}$ Bank syariah tidak meninggalkan fungsinya sebagai lalu lintas pembayaran Internasional, namun demikian mekanisme transaksi valuta asing yang dilakukan oleh bank syariah disusun berlandaskan prinsip syari'ah. transaksi-transaksi valuta asing pada bank syari'ah antara lain: transaksi pembelian atau penjualan valuta asing secara tunai (transaksi spot) dan transaksi forward agreement. Transaksi forward agreement digunakan untuk kebutuhan ekspor dan impor dengan menggunakan mekanisme hedging syari'ah. ${ }^{17}$

Aset atau aktiva yang dimiliki oleh sebuah perusahaan termasuk bank, merupakan sumber daya ekonomi utama, dimana dari sumber tersebut diharapakan mampu memberikan kontribusi baik secara langsung maupun tidak langsung kepada kinerja perusahaan di masa yang akan datang. ${ }^{18}$ Menurut Ismail dalam bukunya akuntansi bank, aktiva adalah harta kekayaan yang dimiliki oleh bank pada tanggal tertentu. Aktiva atau aset bank dapat diklasifikasikan menjadi aktiva produktif (earning asset) dan aktiva tidak produktif (non-earning asset). Aktiva produktif merupakan jenis aktiva yang dapat menghasilkan, aktiva produktif terdiri dari kas, giro, penempatan pada bank lain, efek atau surat berharga, kredit, penyertaan. ${ }^{19}$ Selanjutnya aktiva tidak produktif merupakan jenis aset yang tidak dapat menghasilkan, aktiva tidak produktif terdiri dari aktiva tetap dan aktiva lain-lain. Aktiva tetap terdiri dari, tanah, bangunan, kendaraan dan inventaris kantor. ${ }^{20}$ Sedangkan aktiva lainnya yakni, beban dibayar dimuka, beban yang ditangguhkan, persediaan, rekening antarkantor, titipan nasabah, bangunan dalam penyelesaian. ${ }^{21}$

\section{Metode Penelitian}

Penelitian ini merupakan sebuah penelitian hubungan kausal kontributif (sebab-akibat), yakni penelitian yang digunakan untuk menunjukkan arah hubungan antara variabel bebas dan variabel terikat, serta seberapa besar

\footnotetext{
${ }^{15}$ Adiwarman Azhar Karim, Bank Islam: Analisis Fiqh dan Keuangan, (Jakarta: Raja Grafindo Persada, 2010), 15.

16 Undang-Undang No.10 Tahun 1998 Tentang Perubahan Undang-Undang No.7 Tahun 1992 Tentang Perbankan. 3.

${ }^{17}$ Fatwa Dewan Syari'ah Nasional-MUI no.28. 2002. tentang Jual Beli Mata Uang (al-Sharf),

18 Deden Faturahman, Analisis Faktor-Faktor yang Mempengaruhi Pertumbuhan Total Aset Bank Syari'ah di Indonesia Periode Penelitian 2008-2012, (Skripsi, Universitas Widyatama, 2013), 21.

${ }^{19}$ Ismail, Akuntansi Bank: Teori dan Aplikasi dalam Rupiah, (Jakarta: Kencana, 2014), hal.17.

${ }^{20}$ Ibid, Ismail, Akuntansi Bank: Teori dan Aplikasi dalam Rupiah .., 279.

${ }^{21}$ Ibid, Ismail, Akuntansi Bank: Teori dan Aplikasi dalam Rupiah ..., 16-17.
} 
kontribusi variabel bebas terhadap variabel terikat. ${ }^{22}$ Jenis penelitian menggunakan pendekatan kuantitatif, karena semua data yang dibutuhkan mengacu pada perhitungan yang berupa angka-angka. ${ }^{23}$ Adapun metode analisa data menggunakan uji regresi linear sederhanauntuk mengetahui pengaruh antara variabel bebas dengan variabel terikat.

\subsection{Variabel Penelitian}

a. Variabel Bebas (Independent Variable)

Variabel bebas pada penelitian ini adalah rasio pertumbuhan aset perbankan syari'ah. rasio ini diukur dari data aset bank umum syari'ah yang tertera dalam statistik perbankan syari'ah pada otoritas jasa keuangan (OJK).Perhitungan rasio pertumbuhan aset bank umum syari'ah diperoleh dengan rumus sebagai berikut:

Rasio Pertumbuhan Aset $=\frac{\text { Aset }_{t}-\text { Aset }_{t-1}}{\text { Aset }_{t-1}}$

b. Variabel Terikat (Dependent Variable)

Pada penelitian ini variabel independen yakni fluktuasi nilai tukar rupiah.

Data fluktuasi nilai tukar merupakan data yang diperoleh dari Bank Indonesia (BI), yang merupakan suatu agregat fluktuasi nilai tukar yang terjadi pada sepanjang tahun terkait.

Rasio Fluktuasi Nilai Tukar $=\frac{\text { Kurs }_{t}-\text { Kurs }_{t-1}}{\text { Kurs }_{t-1}}$

\subsection{Metode dan Analisis Data}

Analisa pengujian dilakukan dengan tahap-tahap berikut ini:

a. Uji Normalitas.

Uji normalitas bertujuan menguji apakah dalam model regresi, variabel pengganggu atau residual memiliki distribusi normal. Jika asumsi normal

\footnotetext{
${ }^{22}$ Muhammad, Metodologi Penelitian Ekonomi Islam Pendekatan Kuantitatif, (Jakarta: PT Raja Grafindo Persada, 2008), 19.

${ }_{23}$ Muhammad, Metodologi Penelitian Ekonomi Islam Pendekatan Kuantitatif, (Jakarta: PT Raja Grafindo Persada, 2008), 100-101.
} 
tidak terpenuhi maka uji statistik menjadi tidak valid untuk jumlah sampel kecil. $^{24}$

b. Uji Hipotesis.

Pengujian hipotesis dilakukan untuk mengetahui signifikansi pengaruh variabel independen terhadap variabel dependen. Kemudian pengujian hipotesis juga dilakukan untuk mengetahui seberapa besar kemampuan model dalam menerangkan variabel dependen dengan uji koefisien determinasi $\mathrm{R}^{2}$.

c. Analisis Model Regresi Liniear Sederhana.

Analisis ini menentukan suatu model dalam regresi linear sederhana, dimana variabel terikat tergantung pada variabel bebas. ${ }^{25}$ Hasil analisis regresi berupa konstanta dan koefisien pada variabel independen. Koefisien ini diperoleh dengan cara memprediksi nilai variabel dependen suatu persamaan. ${ }^{26}$

Model umum regresi linear sederhana yakni sebagai berikut:

$$
\boldsymbol{Y}=\boldsymbol{a}+\boldsymbol{b} \boldsymbol{X}_{\text {krs }}+\boldsymbol{e}
$$

\section{Keterangan:}

$\mathrm{Y} \quad=$ Variabel dependen (rasio pertumbuhan aset bank syari'ah)

$a=$ Nilai perkiraan bagi variabel $\mathrm{Y}$ pada saat nilai variabel $\mathrm{X}$ sama dengan nol. (Nilai konstanta).

$b \quad=$ Koefisien Regresi yaitu perubahan rata-rata pada $\hat{Y}$ untuk setiap unit perubahan pada variabel $\mathrm{X}$.

$X_{\text {krs }}=$ Variabel indpenden pertama yang memiliki nilai tertentu (fluktuasi nilai tukar rupiah).

$e \quad=$ Nilai gangguan atau error .

\footnotetext{
${ }^{24}$ Imam Ghazali, Aplikasi Analisis Multivariate dengan Program IBM SPSS 19, (Semarang: Badan Penerbit Universitas Diponegero, 2011), 160.

25 Muhammad Firdaus, Ekonometrika: Suatu Pendekatan Aplikatif, (Jakarta: Bumi Aksara, 2011), 120.

${ }^{26}$ Imam Ghazali, Aplikasi Analisis Multivariate dengan Program IBM SPSS 19, (Semarang: Badan Penerbit Universitas Diponegero, 2011), 95.
} 


\subsection{Populasi dan Sampel Penelitian}

Populasi pada penelitian ini adalah seluruh perbankan syari'ah di Indonesia yang terdiri dari BUS berjumlah 13 bank, UUS berjumlah 21 unit dan BPRS berjumlah 167 bank. Total seluruh populasi penelitian bejumlah 201 bank.Metode penentuan sampel menggunakan purposive judgment sampling, yang merupakan metode penarikan sampel berdasarkan karakteristik anggota sampel yang disesuaikan dengan tujuan penelitian. ${ }^{27}$ Sampel yang digunakan pada penelitian terdiri dari seluruh bank umum syari'ah Indonesia dengan jumlah sebanyak 13 Bank.

\subsection{Data Penelitian}

Data penelitian diperoleh dari situs lembaga terkait yang dipandang relevan. Situs Otoritas Jasa Keuangan (OJK) yakni www.ojk.go.id untuk data aset perbankan syari'ah, dan situs Bank Indonesia yaitu http://www.bi.go.id untuk data agregat nilai tukar. Data tersebut tertera pada tabel berikut ini:

Tabel. 1.1: Data Penelitian

\begin{tabular}{|c|c|c|c|c|}
\hline Tahun & $\begin{array}{l}\text { Rata-Rata } \\
\text { Nilai Tukar }\end{array}$ & $\begin{array}{c}\text { Rasio } \\
\text { Fluktuasi }\end{array}$ & $\begin{array}{c}\text { Total Kekayaan Aset } \\
\text { Bank Syari'ah }\end{array}$ & $\begin{array}{c}\text { Rasio } \\
\text { Aset }\end{array}$ \\
\hline 2016 & 13.240 & $-0,0063$ & $\operatorname{Rp} 254.184 .000 .000 .000$ & 0,356 \\
\hline 2015 & 13.325 & 0,1274 & $\operatorname{Rp} 213.423 .000 .000 .000$ & 0,333 \\
\hline 2014 & 11.818 & 0,1365 & Rp 204.961.000.000.000 & 0,475 \\
\hline 2013 & 10.399 & 0,1140 & Rp 242.276.000.000.000 & 0,491 \\
\hline 2012 & 9.333 & 0,0684 & Rp 195.018.000.000.000 & 0,340 \\
\hline 2011 & 8.736 & $-0,0335$ & Rp 145.467.000.000.000 & 0,242 \\
\hline 2010 & 9.037 & $-0,1263$ & Rp 97.519.000.000.000 & $-0,154$ \\
\hline 2009 & 10.346 & 0,0742 & $\operatorname{Rp} 66.090 .000 .000 .000$ & 0,041 \\
\hline 2008 & 9.631 & 0,0593 & Rp 49.555.000.000.000 & 0,190 \\
\hline
\end{tabular}

Sumber : Bank Indonesia dan OJK, data diolah.

27 Suharyadi \& Purwanto S.K., Statistika Untuk Ekonomi dan Keuangan Modern, (Jakarta: Penerbit Salemba Empat, 2009), 17. 


\section{Hasil dan Analisis Pembahasan}

Adapun hasil dan analisis pembahasan pada penelitian ini adalah sebagai berikut:

\subsection{Uji Normalitas}

\section{Gambar. 1.1}

Uji Normalitas P-Plot

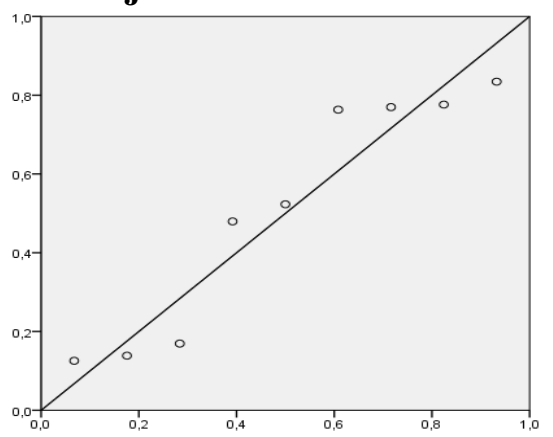

Sumber : Data diolah.

Berdasarkan pada gambar 5.1 di atas, hasil uji normalitas dengan grafik P-Plot menunjukkan bahwa data menyebar di sekitar garis diagonal dan searah mengikuti garis diagonal grafik Normal P-Plot. Hal ini berarti seluruh variabel yang digunakan dalam penelitian memiliki random data yang berdistribusi normal, dengan demikian pengujian statistik berikutnya bisa dilanjutkan.

\subsection{Uji F}

Tabel. 1.2

ANOVA ${ }^{\mathrm{a}}$

\begin{tabular}{|c|c|c|c|c|c|}
\hline Model & $\begin{array}{l}\text { Sum of } \\
\text { Squares }\end{array}$ & $d f$ & $\begin{array}{l}\text { Mean } \\
\text { Square }\end{array}$ & $F$ & Sig. \\
\hline $\begin{array}{ll}1 & \text { Regression } \\
\text { Residual } & \\
& \text { Total }\end{array}$ & $\begin{array}{l}, 179 \\
, 167 \\
, 346\end{array}$ & $\begin{array}{l}1 \\
7\end{array}$ & $\begin{array}{l}\text { 179 } \\
\text {,024 }\end{array}$ & 7,491 &, $029^{b}$ \\
\hline
\end{tabular}

Sumber: Data diolah

Merujuk pada tabel Anova di atas, diketahui bahwa nilai signifikansi probabilitas sebesar 0,029 . Nilai probabilitas tersebut lebih kecil dari $0,05(0,029<$ $0,05)$, dengan ini dapat disimpulkan bahwa variabel independen mempengaruhi variabel dependen. 


\subsection{Uji Koefisien Determinasi (Uji R2)}

Tabel 1.3

Tabel Koefisien Determinasi (R2)

Model Summary ${ }^{\mathrm{b}}$

\begin{tabular}{|l|l|r|r|r|}
\hline Model & $\mathrm{R}$ & R Square & $\begin{array}{c}\text { Adjusted R } \\
\text { Square }\end{array}$ & $\begin{array}{c}\text { Std. Error of } \\
\text { the Estimate }\end{array}$ \\
\hline 1 &, $719^{\mathrm{a}}$ &, 517 &, 448 &, 154434710 \\
\hline
\end{tabular}

a. Predictors: (Constant), Kurs

b. Dependent Variable: Kekayaan_Aset

Sumber: Data diolah

Dilihat dari hasil pengujian pada tabel di atas, tercatat nilai $R$ Square sebesar 0,517 . Nilai ini bermakna bahwa variabel fluktuasi kurs valuta asing menjelaskan $51 \%$ variabel rasio pertumbuhan aset bank syari'ah. Kemudian sisanya sebesar 49 $\%$ dijelaskan oleh variabel-variabel lain.

\subsection{Analisis Persamaan Regresi Linear Sederhana}

Tabel 1.4

Tabel Koefisien

Coefficients $^{\mathrm{a}}$

\begin{tabular}{|c|c|c|c|c|c|c|}
\hline \multirow{2}{*}{\multicolumn{2}{|c|}{ Model }} & \multicolumn{2}{|c|}{ Unstandardized Coefficients } & \multirow{2}{*}{$\begin{array}{c}\begin{array}{c}\text { Standardized } \\
\text { Coefficients }\end{array} \\
\text { Beta } \\
\end{array}$} & \multirow[b]{2}{*}{$t$} & \multirow[b]{2}{*}{ Sig. } \\
\hline & & $\mathrm{B}$ & Std. Error & & & \\
\hline \multirow[t]{2}{*}{1} & (Constant) &, 337 & 059 & & 5,703 & 001 \\
\hline & Kurs & $-1,730$ & 632 & -.719 & $-2,737$ &, 029 \\
\hline
\end{tabular}

a. Dependent Variable: Kekayaan_Aset

Sumber: Data Diolah

Pada tabel. 4.7 menampilkan hasil dari nilai konstanta dan koefisien pada masing-masing variabel. Berdasarkan hasil analisis dan pengujian yang dilakukan menggunakan SPSS 22, maka dapat ditarik suatu bentuk persamaan regresi dalam model estimasi sebagai berikut: 


$$
Y=0,337-1,730 X_{k r s}+e
$$

Keterangan:

$Y=$ Variabel independen rasio pertumbuhan aset perbankan syari'ah

$X_{k r s}=$ Variabel dependen fluktuasi nilai tukar rupiah

Berdasarkan hasil persamaan regresi linear sederhana di atas, tercatat bahwa nilai konstanta sebesar 0,337 . Hal ini menunjukkan bahwa jika variabel fluktuasi nilai tukar rupiah bernilai nol atau konstan, maka rasio pertumbuhan rasio pertumbuhan aset perbankan syari'ah sebesar 0,337.

Koefisien regresi fluktuasi nilai tukar rupiah $\left(\mathrm{X}_{\mathrm{krs}}\right)$ sebesar1,73 dan bernilai negatif. Hal ini menunjukkan bahwa variabel fluktuasi nilai tukar rupiah memiliki hubungan tidak searah dengan variabel rasio pertumbuhan aset perbankansyari'ah. Sehingga kenaikan atau penurunan fluktuasi nilai tukar akan menghasilkan hubungan yang berbanding terbalik dengan variabel rasio pertumbuhan aset perbankansyari'ah. Dengan demikian dapat ditarik kesimpulan bahwa setiap penambahan 1 poin nilai tukar akan menurunkan rasio pertumbuhan aset perbankan syari'ah sebesar 1,73 .

\section{Pembahasan Hasil Penelitian}

Hasil analisis dari uji $\mathrm{F}$ terhadap model penelitian yang diajukan menyatakan bahwa secara signifikan variabel fluktuasi nilai tukar rupiah mempengaruhi variabel rasio pertumbuhan aset perbankansyari'ah.Penelitian ini menghasilkan nilai koefisien regresi sebesar - 1,73. Nilai tersebut memberikan suatu interpretasi bahwa setiap penambahan 1 poin pada nilai tukar (dalam hal ini pelemahan nilai tukar) maka diprediksi akan menurunkan rasio pertumbuhan aset perbankan syari'ah sebesar 1,73. Hasil penelitian ini juga menguatkan penelitian sebelumnya, pada penelitian Saputra dan Rosanna memberikan kesimpulan bahwa kurs atau nilai tukar berpengaruh secara signifikan terhadap tingkat pengembalian pada aset (ROA).

Nilai Koefisien determinasi $\left(\mathrm{R}^{2}\right)$ sebesar 0,51 (51\%) menunjukkan bahwa variabel fluktuasi nilai tukar rupiah mampu menjelaskan $51 \%$ dari rasio pertumbuhan aset perbankansyari'ah, sedangkan $49 \%$ lainnya dijelaskan oleh variabel lain.Hasil ini memperkuat teori Ekananda yang menyatakan bahwa pergerakan kurs akan berdampak pada nilai komoditi dan aset. ${ }^{28}$ Hasil inijuga memberikan tanggapan positif dan sejalan dengan teori yang dikemukakan oleh Dominick Salvatore bahwa segala kegiatan transaksi valuta asing melibatkan pihak bank, dan secara tidak langsung akan tercatat pada debet dan kredit

\footnotetext{
${ }^{28}$ Mahyus Ekananda, Ekonomi Internasiona, (Jakarta: Penerbit Erlangga, 2014), 168.
} 
rekening perbankan. ${ }^{29}$ Hasil dari penelitian ini memberikan interpretasi eksistensi perbankan syari'ah dalam kegiatan transaksi valuta asing. Porsi transaksi valuta asing perbankan syari'ah sudah semakin meningkat. Jika menilik dari data tahunan, angka tertinggi transaksi valuta asing sebesar 51,765 triliun rupiah. Angka tersebut merupakan angka fantastis untuk kategori bank yang notabenenya menerapkan prinsip syari'ah. Fatwa MU-I no.28 menegaskan bahwa terdapat beberapa transaksi valuta asing yang tidak sesuai dengan prinsip syari'ah karena dianggap sebagai transaksi gharar (tidak jelas) dan maysiir (perjudian), transaksi tersebut antara lain transaksi swap, option dan forward. Dalam ayat Al-Qur'an dan Hadits Nabi SAW telah dijelaskan mengenai larangan transaksi gharar dan maysiir:

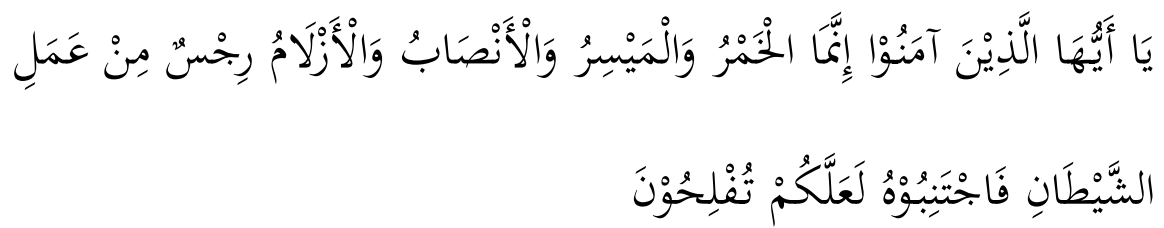

Artinya: "Hai orang-orang yang beriman, sesungguhnya (meminum) khamar, berjudi, (berkorban untuk) berhala, mengundi nasib dengan panah, adalah perbuatan keji termasuk perbuatan syaitan. Maka jauhilah perbuatan-perbuatan itu agar kamu mendapat keberuntungan." (Al-Ma’idah[5]: 90).

Sebagaimana Rasulullah Saw juga bersabda:

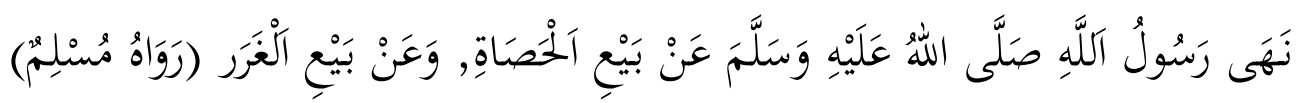

Artinya: "Rasulullah Shallallaahu 'alaihi wa Sallam melarang jual-beli dengan cara melempar batu dan jual-beli gharar (yang belum jelas harga, barang, waktu dan tempatnya). ”(HR. Muslim)

Ayat Al-Qur'an dan Hadits Nabi SAW tersebut menekankan pada setiap muslim secara umum dan juga kepada setiap pelaku ekonomi syari'ah secara khusus untuk tetap selalu berpegang teguh denganpinsip syari'ah pada setiapkegiatan berekonomi. Begitupun halnya dengan pihak bank syari'ah, dengan pangsa pasar transaksi valuta asing yang semakin meluas, hendaknya pihak bank syari'ah harus lebih selektif dalam melakukan transaksi valuta asing. Transaksi-

\footnotetext{
${ }^{29}$ Dominick Salvatore, Ekonomi Internasional.., 5.
} 
transaksi valuta asing tersebut diharapkan dapat berfungsi untuk hal positif dan digunakan untuk kebutuhan hajat orang banyak. seperti halnyapenyaluran dana valuta asing untuk ekspor dan impor (letter of credit), transaksi lindung nilai (hedging) syari'ah untuk memproteksi hutang valuta asing dan tabungan atau talangan dana haji dan umroh untuk memudahkan para nasabah bank syari'ah dalam menunaikan ibadah rukun islam yang terakhir. Dengan demikian kegiatan transaksi valuta asing dapat lebih terarah, sejalan dengan prinsip-prinsip syari'ah, tidak hanya berlandaskan pada prinsip profit oriented semata.

\section{Penutup}

Berdasarkan pemaparan dari hasil analisis dan pembahasan sebelumnya, maka dapat ditarik sebuah kesimpulanbahwa melalui hasil dari Uji $F$ variabel independen yakni fluktuasi nilai tukar rupiah berpengaruh signifikan terhadap variabel dependen yakni rasio pertumbuhan aset perbankan syari'ah.Kemudian hasil dari model summary pada persamaan regresi linear sederhana menyimpulkan bahwa variabel independen fluktuasi nilai tukar rupiah dapat menerangkan 51\% variabel independen, sedangkan sisanya sebesar $49 \%$ diterangkan oleh variabel lain yang tidak masuk dalam model.

\section{Daftar Pustaka}

Karim, Adiwarman Azhar. 2001. Ekonomi Islam Suatu Kajian Kontemporer. Jakarta: Gema Insani.

Al-Asqalani, Al-Hafidz Ibn Hajar. 1998. Bulughul Maram Min Adillatil Ahkam, terj. I.M. Hakim. Hadits No. 806.

Faturahman, Deden. 2013. Analisis Faktor-Faktor yang Mempengaruhi Pertumbuhan Total Aset Bank Syari'ah di Indonesia Periode Penelitian 2008-2012. Skripsi. Universitas Widyatama.

Salvatore, Dominick. 1997. Ekonomi Internasional, Jilid Kedua. Jakarta: Penerbit Erlangga.

Basri, Faisal \& Munandar, Haris. 2010. Dasar-Dasar Ekonomi Internasional, Pengenalan dan Aplikasi Metode Kuantitaif. Jakarta: Kencana.

Fatwa Dewan Syari'ah Nasional-MUI no.28. 2002. Tentang Jual Beli Mata Uang (al-sharf).

Syamsir, Hendra. 2004. Solusi Investasi di bursa saham Indonesia. Jakarta: Elex Media Komputindo.

Ghazali, Imam. 2011. Aplikasi Analisis Multivariate dengan Program IBM SPSS 19. Semarang: Badan Penerbit Universitas Diponegero.

Ismail. 2014. Akuntansi Bank: Teori dan Aplikasi dalam Rupiah. Jakarta: Kencana.

Laporan Keuangan tahunan (annual report). PT Bank Muamalat Tbk. Tahun 2016. 
Ekananda, Mahyus. 2014. Ekonomi Internasional. Jakarta: Penerbit Erlangga.

Firdaus, Muhammad. 2011. Ekonometrika. Suatu Pendekatan Aplikatif. Jakarta: Bumi Aksara.

Muhammad. 2008. Metodologi Penelitian Ekonomi Islam Pendekatan Kuantitatif. Jakarta: PT Raja Grafindo Persada.

Krugman, Paul R. \& Obstfeld, Maurice. 1992. Ekonomi Internasional, Teori dan Kebijakan. Buku Kedua. Jakarta: Rajawali Press.

Lindert, Peter H \& Kindleberger, Charles P.. 1988. Ekonomi Internasional. Edisi Kedelapan. Jakarta: Penerbit Erlangga.

Statistik Perbankan Syari'ah (SPS). Edisi Juni 2017. Otoritas Jasa Keuangan (OJK).

Suharyadi \& Purwanto S. K. 2009. Statistika Untuk Ekonomi dan Keuangan Modern. Jakarta: Penerbit Salemba Empat.

Undang-Undang No.10 Tahun 1998 Tentang Perubahan Undang-Undang No.7 Tahun 1992 Tentang Perbankan. 